\title{
Factors Influencing Return Migration to Rural Origin Communities in The Wa West District of Ghana.
}

\author{
Razak JahaImoro (PhD) \\ Lecturer \\ Department of Sociology and Anthropology \\ University of Cape Coast \\ Ghana
}

\begin{abstract}
While the reasons why people out-migrate internally are relatively well documented in the literature on migration in northern Ghana, not much is known about why people return to their rural origin communities. Using structured interviews, in-depth interviews and focus groups discussions, 300 returnees provided data for the study. Returnees were selected through a multiphase, snowball, convenient, and purposive sampling techniques. Results that the major factors that dominated rural return migrations were care for aged parents, homesickness, extended family demands, and responsibility to occupy traditional authority positions. These results challenge the dominant argument in the theoretical literature which emphasizes failed economic motives as reasons for return migrations. This study provided additional perspectives to thehistorical structural theory and literature on migration in northern Ghana by highlighting individual or micro level factors influencing rural return migration of people to the Wa West District of Ghana.
\end{abstract}

Key words: Migration, Contextual Factors, Returnees, Origin, Rural, Wa West District

\subsection{Introduction}

Human migrations happen everywhere within the globe with different motives and consequences for such migrations. Hence, north-south migration in Ghana is no exception. The phenomenon has been in existence since pre-colonial epochs and persistent and accentuated during colonial and post-colonial times (Abane, 2008; Abudul-Korah, 2008; Tanle, 2010). The mode of these migrations have changed overtime from free rudimentary movements to controlled labour movements during colonial times, to independent rational individuals taking their own decisions to out-migrate in the post-colonial, independence and post-independence eras (Anarfi et., al., 2003; Konseiga, 2005).This is also an indication that northern Ghana has been a net migrant area since the colonial era(Adu-Okoree, 2012; Kwankye, 2012; Ghana Statistical Service, 2014; Yendaw et al., 2016\& 17). For instance, some of the reasons for the out-migrations from northern Ghana include erratic rainfall patterns, poor soil fertility, unemployment, poor economic opportunities, poverty, and lack of social amenities (Adu-Okoree, 2016; Awumbila et. al., 2015, Alenoma, 2013; Tanle, 2010; Imoro, 2011; Van der Geest, 2011). Data from the Ghana Statistical service (2014) further emphasize this outflow of migrants from northern to southern Ghana as shown in Table 1.

Table 1: In-Migration, Out-migration and Net Migration of the three regions in Northern Ghana

\begin{tabular}{lllll}
\hline Region & In-migration & Out-migration & $\begin{array}{l}\text { Out-migration } \\
\text { Rate (in \%) }\end{array}$ & Net-Migration \\
\hline Upper West & 43,427 & 252,841 & 31 & $-209,414$ \\
Upper East & 61,298 & 328,990 & 24 & $-267,692$ \\
Northern & 100,524 & 433,121 & 25 & $-332,597$ \\
\hline
\end{tabular}

Source: Ghana Statistical Service, 2014

While the reasons for the out-migration from northern to southern Ghana have been widely documented, little is known about return migrations from southern to northern Ghana. Specifically, the factors that influence these reverse migrations especially to rural origin communities in northern Ghana.People return to their rural origin communities after several years of stay in a destination area remains under researched particularly in the Ghanaian context. The study uses the Wa West District in the Upper West Region of Ghana as a case study. Thus the discussion of this topic was done as follows; the introduction, the next section of the paper presents the literature and theoretical as well as the conceptual framework underpinning the study. The third section details the methods used in the study whiles the fourth 
section chronicles the views of returnees about their migration to origin communities. The final section draws conclusions and proposes recommendations.

\subsection{Factors influencing return migrations: A Literature review}

A crucial aspect of internal migration is return migration either from urban-rural or rural-rural or rural- urban or urbanurban. The discourse on internal return migration indicates that it could be driven by several factors ranging from social, political, economic as well as cultural (Castelli, 2018). Meanwhile, the debate on this subject has been that, the above mentioned factors are more prominent in the return migration phenomenon. Whiles other authors highlight the preponderance of economic factors (Claver, 2013; Dziva \& Kusena, 2013;Junge, Revilla \& Schatzl, 2013). Thiswrite up is of the view that non-economic factors are prominent particularly to rural return migrations. For instance, people return to their rural communities because of personal issues such as death of relative, divorce, poor health, homesickness and the desire to raise children at home (Thanh, Lebailly, Dien, 2019; Chobanyan, 2013; Koehler, Laczko, Aghazarm, \& Schad, 2010). These factors underscore the relevance of personal and social related matters in a return migration phenomenon. The fact that people would return to their origin communities due to health or homesickness indicates the urgency people attach to their origin areas. In the return migration of rural residents in the United States, Cromartie von Reichert, and Arthun (2015) emphasized the primacy of family considerations as factors responsible for people returning.

In a similar breadth, affordable housing and encouragement from friends and family in origin communities also spared off return migrations in rural Scotland(Crow, 2010). The presence of good old friends in origin communities in addition to the nostalgic atmosphere that returnees may have missed for some period constitute strong driving forces of return migration.Additionally, Wang and Fan (2005) and Piotrowski and Tong (2010)revealed that having close family members (spouse, children, or mother) in the origin community can orchestrate a return migrationin rural Thailand.The wish to rejoin family and friends, homesickness, and the quest to enjoy an improved social status back home are significant reasons for return migration (Thanh, Lebailly, Dien, 2019; Tenkorang, 2014; Yendaw \& Tanle, 2015). Other scholars such as Adebo and Sekumade (2012), attributed rural return migration in Nigeria to interaction with village peer groups, contribution to extended family life, moving closer to family and friends, and contribution to family development. In addition,Tenkorang (2014) identified personal and family reasons as drivers of return migration to the Wa Municipality in the Upper West region of Ghana. In the same vein Ainsaar (2004) identified family, and availability of housing as reasons responsible for rural return migration in Estonia with Hirvonen and Helene (2012) indicating marital issues as well as the need to follow inheritance due to death of a parent as factors influencing return migrations in rural Tanzania.

\subsection{Theoretical Perspective}

Several theoretical perspectives also inform the return migration discourse. These include micro theories such as network, human investment, transnational theories and macro theories including; neo-classical, new economics of labour migration, and the historical structural theories. Particular preference is given to the historical structural theory in this paper (see also Gunder, 1969; Amin, 1974;Wallerstein, 1980). Often in the theoretical literature, this theory is used to explain international migration, meanwhile the tenets and principles of the theory can also explain rural internal return migrations. This is because it emphasizes the influence of contextual factors which drives return migrations (Castles \& Miller, 2003; Cassarino, 2004; Morawska, 2012), a major issue highlighted in this paper. The theory argues that certain factors at origin communities of migrants compel them to return to their places of origin. These factors are termed contextual owing to their context specific characterization (Wang \& Fan, 2006; Cassarino, 2004).

The thrust of this paper is that, contextual factors can dominate the reasons for return migration and not whether the migrant was a failed or a successful returnee (Wang and Fan, 2006). This position is underpinned by the historical structural theory. The theory rejects the positions of the neo-classical and the new economics of labour migration theories which emphasize economic factors of return migration. However, the success or failure of returnees cannot necessarily be financial in nature. Social, political and cultural reasons can influence return migrations and not just because returnees fail to accumulate savings during their period of migration. Issues of power relations, traditional values, customs and norms and other culturally constraining factors at places of origin have a strong impact on rural return migrations (Stark, 1980; Bloom, 1985; Levhari, 1982; Cassarino, 2004; Morawska, 2012). The theory also emphasizes the role of customs, traditions and other socially or politically coercive factors at origin communities driving return migrations (Cassarino, 2004). 
The historical structural theory is relevant because it views success or failure in relation to the reality of the origin community of the returnee and not the externally imposed understanding of success defined by the savings, and material accumulation of the returnee (Stark \& Levhari, 1982; Stark \&Bloom, 1985; Tylor, 1999; De Haans, 2008).

On the downside, the theory tends to over focus on the macro rather than the micro factors in the spectrum of factors that underpin the discourse on migration. Thus, individual level factors which also strongly influence return migrations have been neglected by the theory. This theoretical gap is what this research intends to fill through extending the analysis to cover micro level factors that drive rural return migrations.

\subsection{Conceptual framework}

This study adapted Black, Atfield, Koser, Munk, d'Onorio and Tiemoko (2004) conceptual framework on factors influencing return decisions of individuals. It identified the various factors that inform the migration decision-making process. The literature show that few conceptual frameworks exist to explains rural return migrants' decision making processes (Koser, 2013). This explains the use of Black et al. (2004). The framework outlined the levels within which factors influencing return decisions of individuals operate, i.e. whether they are at the structural, individual or policy interventions level. The theoretical position of this paper is that contextual factorsinfluenced rural return migration decisions, and this can be situated within the framework proposed by Black et. al., (2004). This is because these contextual factors can operate at the structural, individual and policy interventions levels. More importantly, the framework examined the conditions of migrants in both the destination and origin areas. These conditions which are usually structural in nature, in addition to individual and social factors, combined to influence the return decision making process of people. Nonetheless, certain policy interventions could also influence return decision making such as new government projects in agriculture or change in the political atmosphere in the origin community. Figure 1 presents Black et. al, (2004) framework below.

\section{Figure 1: Factors influencing return decisions of individuals}

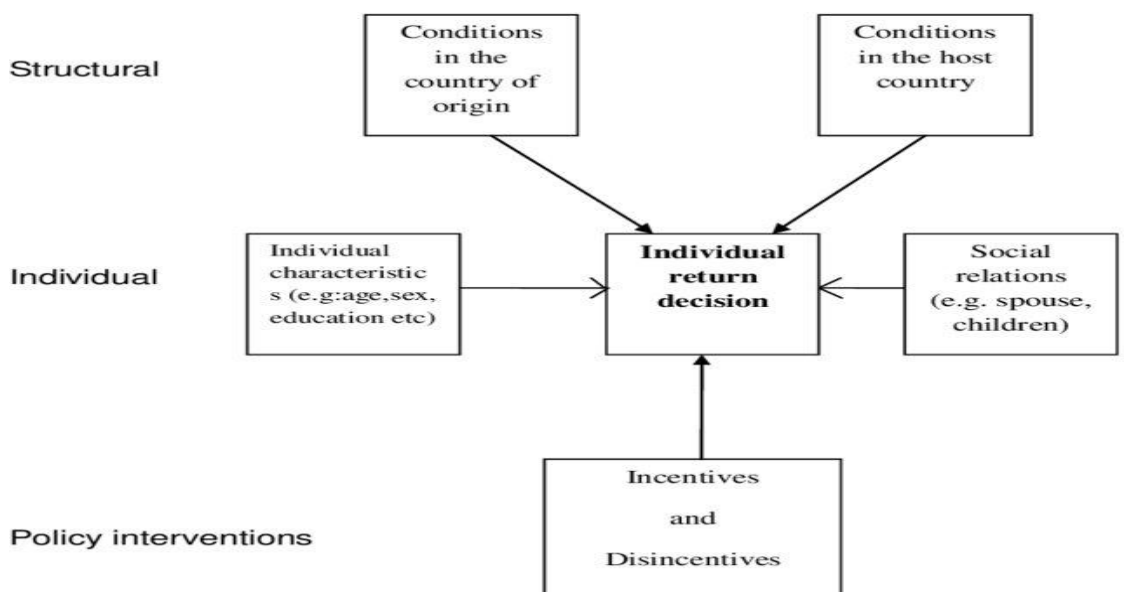

Source: Black et.al. (2004)

The framework was adapted to suit the factors discussed in the text. The factors in origin communities including presence of family members, extended family demands, coercive nature of values and customs,traditional power relations constitute structural factors that influenced individual decisions to return to their rural origin communities. This is a community where the economy of affection is pervasive and relationship between people is based on traditional kin groups where clans and lineage associations govern traditional ways of life. These factors impinge on the smooth stay of migrants in destination areas and thus influence return decisions. The study further found that the individual characteristics of migrants (e.g. sex, age, marital status, number of children) and social factors (e.g. care for the aged, extended family demands, homesickness) have influenced return migrations to the study area.The framework ties in with the theoretical perspective-historical structural theory- which posits that it is the contextual conditions in origin and destination areas that drive return migrations and these contextual factors include the structural, individual as well as social factors that this framework espouses. Similarly, this study unearthed the influence of contextual factors which are structural, social and individual related factors driving return migration to the Wa West District. Figure 2 presents the adapted framework as shown below. 
Figure 2: Factors influencing return decisions of individuals

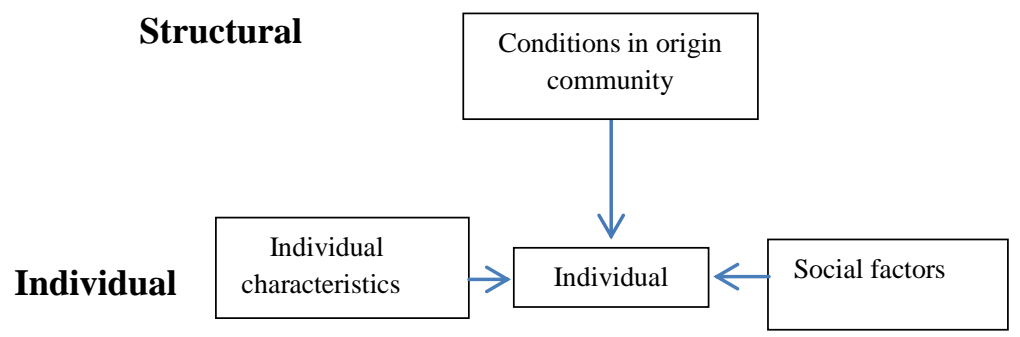

Source: Adapted from Black et. al. (2004)

\subsection{Location, size and physical characteristics of the study area}

The Wa West District is among the 28districts in Ghana that were created in 2004 as part of the decentralization process. Located in the Upper West Region, the district comprises of five Area Councils: Dorimon, Ga, Gurungu, Vieri and Wechiau (the District Capital) with approximately 227 communities.Geographically, the Wa West District is located in the North Western part of the Upper West Region. It stretches from longitudes $40^{\circ} \mathrm{N}$ to $245^{\circ} \mathrm{N}$ and from latitudes $9^{\circ} \mathrm{W}$ to $32^{\circ} \mathrm{W}$, as shown in Figure 2 below. The district shares boundaries with Sawla-Tuna-Kalba District to the south in the Savannah Region, Wa Municipality to the east, Nadowli District to the north and to the West with Ivory Coast as shown in Figure 2. It constitutes about 10 percent of the region's total land area, which is estimated at 1856 square kilometres (Wa West District Assembly, 2013). According to the Ghana Statistical Service (2012), the total population of the District stands at 81,348 comprising 40,227 (49.5 percent) male and 41,121 (50.5 percent) female. The preponderance of more females than males mirrors the general demographic trend in the country where there are more females than males (Wa West District Assembly, 2013; Ghana Statistical Service, 2012).

Figure 3: Map of the Wa West District showing the study areas

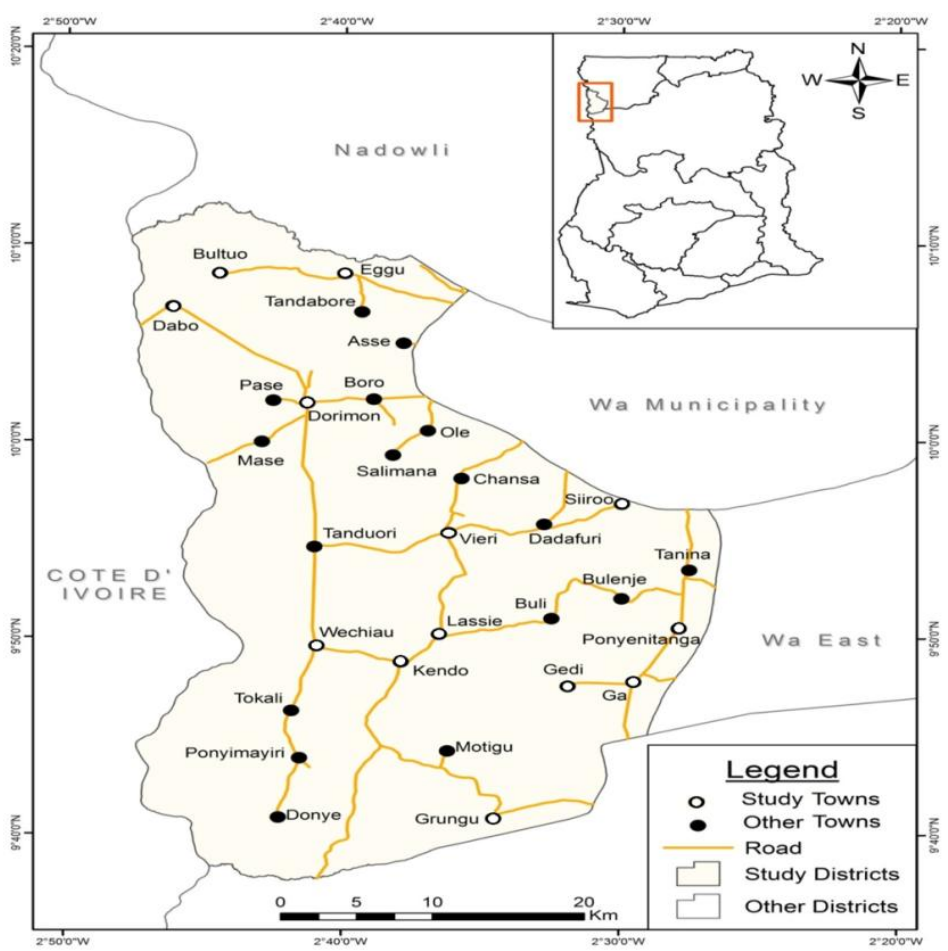

Source: GIS, Department of Geography and Regional Planning, UCC, 2014 


\subsection{Research Methods}

\subsection{Study Population}

The study population comprised two categories of respondents; return migrants and non-migrants. Return migrants constituted natives of the Wa West district who had settled in the southern parts of Ghana for at least five years and had returned to the District within the last five years. The five-year time period was chosen because it is long enough for returnees to have settled into their communities and had a good appreciation of the conditions to which they had returned. Besides, the period is not also too long for returnees to forget their motivations. Non-migrants constituted natives of the district who never migrated. The sample units constituted adults aged 18 years and above. This is because by 18 years an individual is considered matured to take independent decisions for him or herself with regards to migration.

\subsection{Sample size and sampling techniques}

The sample size for return migrants was arrived at using both probability and non-probability sampling techniques. The selection of returnees in the district was done using the multi-phase sampling procedure. In applying this method, first the area councils in the district were used to target returnees. Secondly, a preliminary visit by the researcher to communities within the district revealed the concentration and availability of returnees in some communities as compared to others. In all 27 communities were visited and900 returnees were sampled. Out of this number, 300 returnees were interviewed. The sample of 300 respondents from an assumed population of 900 supports Krejcie and Morgan's formula for sample size determination (Krejcie and Morgan, 1970).

\section{Table 2: Returnees identified and number selected}

\begin{tabular}{llll}
\hline Respondents & Methods & $\begin{array}{l}\text { Data collection } \\
\text { instrument }\end{array}$ & $\begin{array}{l}\text { Sample size interviewed } \\
\text { and where }\end{array}$ \\
\hline Returnees & Structured interviews & Interview schedules & $\begin{array}{l}300 \text { respondents in 27 } \\
\text { communities in the } \\
\text { District }\end{array}$ \\
$\begin{array}{l}\text { Key informants } \\
\text { Returnees }\end{array}$ & In-depth interviews & Interview Guide & $\begin{array}{l}6 \text { key informants' } \\
21 \text { interviewees from 13 } \\
\text { communities }\end{array}$ \\
$\begin{array}{l}\text { Opinion leaders, } \\
\text { elders, Assembly interviews } \\
\text { members, }\end{array}$ & Focus Group Discussion & Interview Guide & Focus group \\
Discussion guide & focus group discussions \\
\hline
\end{tabular}

\section{Source: Fieldwork, 2015}

In the selection of respondents, first, a snowball sampling technique was employed, where one returnee identified and interviewed suggested other known returnees whom they knew lived within the community and these were easily contacted (Boateng, 2012; Walter, 2010). One major disadvantage with this method was that it was unrepresentative of the population, and hence the aim of using it in this research was to have quick access to return migrants. A convenient sampling was also employed where the researcher took advantage of village market days to interview respondents. This method was easy and inexpensive and helped to gather adequate data within a short time (Babbie, 2007; Babbie, 2010).Furthermore, through purposive sampling other returnees (21 returnees) were identified and used as key informants for the in-depth interviews. The non-migrant population made up of key informants, were also selected purposively. The reason for using purposive sampling was to get respondents who have knowledge about these returnees and could provide accurate information on the subject matter. The approach also helped to corroborate responses given by returnees and enrich the analysis and discussions (Walter, 2010).

\subsection{Methods and Instruments}

The study adopted a mixed methods approach which combined both quantitative and qualitative methods. These included: in-depth interviews, structured interviews and focus group discussions. Interviews are managed verbal exchanges and as such their effectiveness depend on the communication skills of the interviewer (Bryman, 2008). This method allowed for a common language to be used to elicit detailed information about reasons for rural return migration to the Wa West District (Bryman, 2008; Boateng, 2012). An interview guide was used to collect data from returnees and key informants on the factors influencing rural return migration to the Wa West District. 
In addition, structured interviews which involved asking every respondent a list of predetermined questions about return migration was employed to help gather comprehensive data on the subject. Questions asked were in a standardized order and every respondent responded to the same set of questions. This instrument was used owing to the fact that it was easy to replicate as a fixed set of closed questions were used, which also made it easy to quantify the results generated from the interviews.

Lastly, focus group discussions were conducted at various locations in the study area. These were structured, freeflowing interviews with a group of non-migrants, usually between six and ten members per each discussion group(Rosalind \& Holland, 2013). Five focus group discussions were conducted, all composed of mixed gender and age range of 27 to 50 years. This method was chosen because it addressed the opinions, perceptions, views and expectations of key informants about return migration.

\subsection{Data Collection}

On the average, in-depth interviews and structured interviews lasted for a minimum of thirty minutes and a maximum of one hour with focus group discussions lasting for an hour or more. Interview environments were well moderated even though some interview sessions were emotional as some respondents shared their experiences with interviewers. There were also cases where interviews were challenging as respondents resisted certain questions and questioned the veracity of interviewers. The use of the face to face approach allowed for common language to be used given the low level of the literacy status of respondents. In the district 36.7 percent of the population 11 years and above are literate and 63.3 percent are non-literate (Ghana Statistical Service, 2014). Whilst interviews and focus group discussions were recorded with the aid of a recorder, structured interviews were answered in the schedule.

\subsection{Ethical Considerations}

Behaviour could be difficult to understand and hence in dealing with humans'care, attention, and trust must be sought. The study adhered to ethical principles that guaranteed that data generated were reliable and trustworthy. The dignity, rights, safety and well-being of participants were of primary consideration. Respondents were informed about the aim, purpose and use of the research results. This made respondents to feel free to express their candid opinions as much as possible. Consent of respondents were adhered to as they were provided with detailed information about the study and their right to opt out. The inform consent allowed respondents to decide whether or not to participate in the study. The privacy of respondents was also duly respected. The cultural context within which this research was conducted demanded that privacy be given maximum premium. Meanwhile, information was treated with anonymity without assigning names or identities. This further implied that confidentiality was key to this research. Information or data was confidential without any attempt to divulge respondents' information to another respondent or to the general public without due process. Crucial in the data collection process was non coercion on the part of the researcher for respondents to provide information. Voluntariness in participation of the research was guaranteed. Respondents' right to exercise choice was present throughout the entire research process.

\subsection{Data analysis and analytical techniques}

The qualitative data was analysed using the thematic approach. First, the data from in-depth interviews and focus group discussions were all transcribed into English as narrated by interviewees and participants respectively. Secondly, these transcripts were cleaned by checking for consistency and accuracy of responses. After cleaning, themes were identified with the study objective in mind (Emily et al., 2007; Onwuegbuzie \& Leech, 2012). The structured interview instruments were analysed using Statistical Product and Service Solutions (SPSS) version 21 where responses were entered and analysis generated. Tables, frequencies, percentages, cross tabulations were generated, analyzed and interpreted.

\subsection{Results}

\section{Demographic Characteristics of Returnees}

\subsection{Age and Sex distribution of returnees}

Return migration is age selective. For instance, older ages tend to return to origin communities whiles the younger age groups are more likely to out-migrate(Wang \& Fan, 2006; Beauchemin \& Bocquier, 2011).The results in Table 3 indicate that majority of returnees fell within two age categories (50-59 and 60-69 years) which together constituted 60.7 percent with more males $138(68.33 \%)$ as compared to females $37(32.3 \%)$. This may be due partly to the fact that more males than females out-migrated (Awumbila, 2015). The low number of females could also be because most of the females were left behind as wives to take care of children at their origin communities whiles only men out- 
migrated. Additionally, the patriarchal nature of the district and the power relations between men and women could as well influence return migration of more males as compared to females. The literature is skewed in favour of males as far as return migration is concerned, indicating that more males return to their origin communities than females in most return migrations in West Africa (Adepoju, 2010). Also, Gubert and Nordman (2008) revealed that large majority of returnees were usually males and aged between 41-49 years, further adding to the evidence that men dominate the return migration flows as compared to women.

Table 3: Age and sex distribution of returnees

\begin{tabular}{llcc}
\hline Age & \multicolumn{1}{c}{ Sex } & Total \\
& & Female & \\
\hline $20-29$ & $7.0(63.6 \%)$ & $4.0(36.4 \%)$ & $11(3.6 \%)$ \\
$30-39$ & $12(60 \%)$ & $8.0(40 \%)$ & $20(6.7 \%)$ \\
$40-49$ & $17(50 \%)$ & $17(50 \%)$ & $34(11.3 \%)$ \\
$50-59$ & $76(72.4 \%)$ & $29(27.6 \%)$ & $105(35 \%)$ \\
$60-69$ & $52(67.5 \%)$ & $25(32.5 \%)$ & $77(25.7 \%)$ \\
$70-79$ & $41(77.4 \%)$ & $12(22.6 \%)$ & $53(17.7 \%)$ \\
\hline Total & $\mathbf{2 0 5}(\mathbf{6 8 \%})$ & $\mathbf{9 5}(\mathbf{3 2 \%})$ & $\mathbf{3 0 0}(\mathbf{1 0 0 \%})$ \\
\hline
\end{tabular}

Most of these returnees were above the active working age group (15-45 years) even though they could remain economically active and engage in some economic activities following their return migration (De Vreyer, et al., 2010;Falkingham, Chepngeno-Langat and Evandrou, 2011). The young and active age groups (20-29, 30-39, and40-49 years) together recorded 21.7 percent of the total sample whiles the very old age group 70-79 also recorded 17.7 per cent of the sample. In terms of decision to return to origin communities on the basis of sex it was found that males were more willing to return to origin communities as compared to the females as shown in Table 4.

Table 4: Sex and decision to return to origin community

\begin{tabular}{llll}
\hline Sex & \multicolumn{2}{l}{$\begin{array}{l}\text { Decision to return to origin } \\
\text { community }\end{array}$} & Total \\
& Yes & No & \\
\hline Male & $179(67.8 \%)$ & $26(72.2 \%)$ & $205(68.3 \%)$ \\
Female & $85(32.2 \%)$ & $10(27.8 \%$ & $95(31.7 \%)$ \\
\hline Total & $\mathbf{2 6 4 ( 8 8 \% )}$ & $\mathbf{3 6}(\mathbf{1 2 \%})$ & $\mathbf{3 0 0 ( 1 0 0 \% )}$ \\
\hline
\end{tabular}

Reasons for return migrations to origin communities ranged from economic, social, cultural and political (Castelli, 2018). Males were more interested in returning owing to factors in origin communities compelling their return migrations. These factors included care for aged parents at origin communities, homesickness experienced by returnees, extended family demands at origin communities, and traditional leadership position. Also ages of returnees were positively associated with decisions to return to origin communities (see Table 5).

Table 5: Age and decisions to return to origin community

\begin{tabular}{|c|c|c|c|c|}
\hline & & \multicolumn{2}{|c|}{ Decision to return to origin community } & \multirow[t]{2}{*}{ Total } \\
\hline & & Yes & No & \\
\hline \multirow[t]{6}{*}{ Age } & $20-29$ & $11(100 \%)$ & 0 & $11(3.6 \%)$ \\
\hline & $30-39$ & $16(80 \%)$ & $4(20 \%)$ & $20(6.7 \%)$ \\
\hline & $40-49$ & $29(85.3 \%)$ & $5(14.7 \%)$ & $34(11.3 \%)$ \\
\hline & $50-59$ & $96(91.4 \%)$ & $9(8.6 \%)$ & $105(35 \%)$ \\
\hline & $60-69$ & $63(81.8 \%)$ & $14(18.2 \%)$ & $77(25.7 \%)$ \\
\hline & $70-79$ & $49(92.5 \%)$ & $4(7.5 \%)$ & $53(17.7 \%)$ \\
\hline Total & & $264(88 \%)$ & $36(12 \%)$ & $300(100 \%)$ \\
\hline
\end{tabular}

Decisions to return to origin communities increased with age and vice versa.The younger age groups were not willing to return to origin communities as compared to the aged. Consequently, decisions to return to origin communities were age related. Extensive studies showthat returnees were mostly retirees, males and between 61-70 years of age (Adebo \& Sekumade, 2012; Zai, 2011).Reasons for such old aged return migration included: retirement, old age, economic 
conditions in destination areas and unemployment or lack of jobs in destination areas (Devreyer, Gubert, Robilliard, 2010).

\subsection{Marital status of returned migrants}

The marital status of a migrant could influence return migration decisions. This is because decisions to return to origin community cannot be taken independently by one spouse at destination area (Adebo and Sekumade, 2012; Zai, 2011). Table 6 displays the marital status of returned migrants.

Table 6: Marital Status of returned migrants

\begin{tabular}{lcc}
\hline Marital Status & Frequency & Percentage \\
\hline Married & 246 & 82 \\
Never Married & 24 & 8 \\
Separated & 6 & 2.0 \\
Divorced & 4 & 1.3 \\
Widowed & 16 & 5.4 \\
Informal consensual Union & 4 & 1.3 \\
\hline Total & $\mathbf{3 0 0}$ & $\mathbf{1 0 0 . 0}$ \\
\hline
\end{tabular}

Majority of the returnees were married, and this could have influenced return decisions of spouses. Eight percent of returnees were never married, while 10 percent were separated, divorced, widowed or in an informal consensual union. For instance, divorce and widowhood can influence return migration decisions (Bijwaard \& Doeselaar, 2012). Also,Cromartie, von Reichert, and Arthun (2015) and Stella (2012)have concluded that returnees were usually more likely to be married, employed, working in a professional or managerial position, and better educated. The marital status of returnees was also found to be positively associated with the decisions to return to their origin communities (See Table 7).

Table 7: Marital status and decision to return to origin communities

\begin{tabular}{lllll}
\hline & \multicolumn{3}{c}{ Decision to return to origin community } & Total \\
\cline { 2 - 5 } & & Yes & No & \\
& never married & $20(80 \%)$ & $5(20 \%)$ & $25(8.3 \%)$ \\
\multirow{5}{*}{ Marital status } & $4(100 \%)$ & 0 & $4(1.3 \%)$ \\
& informal consensual union & $217(88.9 \%)$ & $27(11.1 \%)$ & $244(81.3 \%)$ \\
& Married & $5(83.3 \%)$ & $1(16.7 \%)$ & $6(2.0 \%)$ \\
& Separated & $3(75 \%)$ & $1(25 \%)$ & $4(1.3 \%)$ \\
& Divorce & $14(87.5 \%)$ & $2(12.5 \%)$ & $16(5.3 \%)$ \\
\cline { 2 - 5 } Total & Widowed & $\mathbf{2 6 3}$ & $\mathbf{3 6}$ & $\mathbf{3 0 0}(\mathbf{1 0 0 \%})$ \\
\cline { 2 - 5 } & & & & \\
\hline
\end{tabular}

Approximately, 89 percent of married returnees decided to return to their origin communities as compared to other returnees. This could be due to difficulty in caring for the household and the socio-economic conditions in the host community which may not permit a permanent stay. Other respondents such as the never married (80\%) and the widowed $(87.5 \%)$ showed that their decisions to return to origin communities were partly due to their marital status. Such return migrations may be to consummate marriage arrangements or to take up family or lineage responsibilities (Kudo, 2012; Beegle \& Poulin, 2013).

\subsection{Level of education of returned migrants}

The literature has widely documented the influence of education on out migration (Corbelt, 2008; Devreyer et al., 2009; Borodak \& Piracha, 2010). It is also known that the highly educated turn to out-migrate more even among rural communities as compared to the less educated. From tables 8 and 9the less educated returnees were more likely to return to their origin communities as compared to the highly educated. 
Table 8: Level of education of returned migrants

\begin{tabular}{lrr}
\hline Level of education & Frequency & Percent \\
\hline No level of education & 239 & 79.3 \\
Primary/SHS & 35 & 11.7 \\
Vocational/Technical & 9 & 3.0 \\
Post-secondary & 4 & 1.3 \\
Tertiary & 13 & 4.3 \\
\hline Total & $\mathbf{3 0 0}$ & $\mathbf{1 0 0 . 0}$ \\
\hline
\end{tabular}

The results show that a significant proportion of returnees (79.3 percent) did not have any level of education with only 11.7 percent having primary or senior high school as their highest level of education. Respondents with tertiary education were 4.3 percent and post-secondary level recorded 1.3 percent. Studies have shown to the contrary that the literacy levels of returnees could be high (Hui Xu, 2010;Devreyer et al., 2009). This was however not the case in this research.

Table 9: Level of education and decisions to return to origin communities

\begin{tabular}{lllll}
\hline \multicolumn{5}{c}{ Decision to return to origin community } \\
\hline & Yes & No & Total \\
& No education & $211(88.7 \%)$ & $27(11.3 \%)$ & $238(79.3 \%)$ \\
& Primary/SHS & $28(80 \%)$ & $7(20 \%)$ & $35(11.7 \%)$ \\
& Vocational/Technical & $9(100 \%)$ & 0 & $9(3.0 \%)$ \\
\multirow{3}{*}{ Level of Education } & Post-Secondary & $4(100 \%)$ & 0 & $4(1.3 \%)$ \\
& Tertiary & $12(85.7 \%)$ & $2(14.3 \%)$ & $14(4.7 \%)$ \\
\cline { 2 - 5 } & & $\mathbf{2 6 4 ( 6 8 \% )}$ & $\mathbf{3 6 ( 1 2 \% )}$ & $\mathbf{3 0 0 ( 1 0 0 \% )}$ \\
\hline
\end{tabular}

\subsection{Factors influencing return migration to the wa west district}

The findings of the study showed that returnees were generally more males, aged, married and uneducated with large family sizes and were into cash crop farming activities in their destination areas in southern Ghana (Tanle, 2014; Van der Geest, 2011). Age influence's migration in diverse ways for instance younger ages tend to out-migrate while the older ages tend to return to origin communities (Van der Geest, 2011). Migration in the Wa West District could be described asa male dominated activity even though female migration is on the increase. Several factors necessitated return migration to the Wa West district after migrants stayed in their destination areas in southern Ghana for between 5-10 years on the average. These included extended family responsibilities, homesickness, education of children and occupying traditional leadership position (See Table 10). As indicated in section 2.2 the characteristics of returnees with regards to their sex, ages, and marital statuses have influenced their return migrations decisions. This brings to the fore the conceptual framework that guides the study as it captures the individual characteristics of migrants as key factors in their return decision making processes.

Table 10: Factors influencingreturn migration

\begin{tabular}{lcc}
\hline Factors & Frequency & Percentage \\
\hline Take care of aged parents & 205 & 68.3 \\
Home sicknesses & 196 & 65.3 \\
Extended family demands at home & 121 & 40.3 \\
Education of children & 85 & 28.3 \\
Occupy traditional authority position & 19 & 6.3 \\
\hline
\end{tabular}

$\mathrm{n}=300$; Total number of responses is more than total number of respondents due to multiple responses

Source: Fieldwork, 2014

As shown in Table 8, migrants returned to their origin communities because of extended family responsibilities which included taking care oftheir aged parents (68.3 percent). Piotrowski and Tong (2010) and Crow (2010) have pointed to the significance of having close family members (spouse, children, mother etc) in the origin community as a driver of return migration. Family reasons influenced return migration intentions and decisions to origin communities. This is because people attach close affinity to family issues and families invariably play a crucial role in supporting members to out-migrate. Therefore, where migrants see their family members as sources of bonding and support, return migrations occurred to satisfy such family demands. This is confirmed by the narrative of a 40 -year-old returnee. 
I went to Sefwi in the Western Region with my husband where we worked in cocoa farms. When we went we knew that after sometime we would return home but we didn't specify whichever time we would come back. We stayed for seven years and my husband's senior brother who was taking care of my husband's mother passed away and there was nobody to take care of my mother in-law who was old and my husband insisted we should return home. So we came back home [40-year-old female returnee, from Samambo Village].

Furthermore, returnees as members of extended family households were called upon to support family members in times of difficulties such as funerals, and traditional ritual practices. These demanded frequent visits back home from their destination areas and eventually culminating into permanent return migrations (Black \& Castaldo, 2008; De Haans, 2008). This was summed up in the words of a 35-year- old male returnee.

I out-migrated because I wanted to acquire some investment so I can come back and support myself. But whiles in the south I was constantly been called to come back home for funerals and so whatever money I get it was always spent on transportation. This is because I am always called upon in times of such difficulties. So I decided to come back home so I can be closer and with my other extended family members we can easily handle such problems [35-year-old male returnee from Samanbo village].

As pointed out in section 2.1, the reasons why people would return to their origin communities after some period of stay in a destination area are individually and contextually dependent. This re-enforces the historical structural theoretical perspective. The traditional practice of inheritance in the Wa West District where a male son must take over the father's estate after the death of the father was one family reason driving return migration (Nukunya, 2000;Gandaa, 2013).In addition, the area has a communal nature of social organization where people are related based on clan, lineage and descent systems and succession is patrilineal. Return migration is an integral part of maintaining that bond and affinity with clan and kin group which helps in the survival of the community or society at large. People owe their social responsibilities to the family (Yendaw et al., 2017).

The family in this regard is the main social support system in the area. Hence strong family ties were largely responsible for return migrations as highlighted in the literature (see e.g: Thanh, Lebailly, Dien, 2019; Tenkorang, 2014; Yendaw \& Tanle, 2015).

Another key factor responsible for return migration to the Wa West District was "home sickness". To be home sick means sadness or depressed from a longing for home or family while away from home for a long time (Thomas-Hope 2002). Some returnees longed for their families and home after several years of stay in their destination areas resulting in their return migrations. The concept of "home is home" played out significantly in the explanations returnees gave for their return migrations. Returnees' reminiscence that after a long stay in a new area the ultimate end is to return home. As people out-migrated, they experience a different world and also imbibe changed values and culture hence after some period of stay in a new destination they obviously relish their origin communities with its associated activities and culture including festivals, food and ways of life. The presence of friends in origin communities as well as the nostalgic atmosphere that returnees may have missed for some periods all resulted in return migrations (Crow, 2010; Chobanyan, 2013; Tenkorang (2014)).A 50-year-old male returnee captures this succinctly in this narration:

I went to the south and stayed for over seven years. I had all my five children down south. I decided to return because I think as a man when you travel out for such a long time you definitely would want to return one day. It is only proper that I returned after all I had left behind loved ones, friends and relatives and it is only normal to return to see how they are faring. I was always interested in returning because I was not closer to my parents and this is the time I need to stay with them and show them love before they pass on to the next world [50-year-old returnee from Dorimon Village Interview 1].

Homesickness can also be viewed as a crucial personal factor of the returnee that can drive a return migration as they influence the individual return decisions of migrants (Thomas-Hope, 2002). This generally mirror into the broader frame of family factors influencing a return migration. As explained in section 2.2, social reasons such as family reasons are key drivers of return migration decisions. Hence strong family ties in the home community, obligation to relatives, feelings of loyalty, guilt for living outside one's community constitute some of the factors responsible for return migrations (Wang \& Fan, 2005; Piotrowski \& Tong, 2010; Yendaw et. al, 2017). Factors such as homesickness influencing return migration sit within the domain of the historical structural theories which echoes contextual factors as responsible for return migrations. Reasons for return migrations go beyond the question of savings or investment advantages to emphasize the role of customs, traditions and socially or political coercive factors that compels return migration (Cassarino, 2004; Morawska, 2012). 
Occupying traditional authority position means a situation or circumstance where returnees were called upon to take over responsibilities and duties as leaders in their families, clans or lineages as either family heads or clan heads. Some occupied positions as heads of family shrines and took charge of family religious practices. This was another critical factor influencing return migrations to the Wa West District. Family responsibilities are a basic function of family members and therefore performing such duties is a core function of most families in Africa. Just as Mbiti (1975) noted that each person in Africa traditionally lives in or as a part of the family.

Some of these people return because when they stay down south, and, also considering the fact that at home they are next to take up leadership positions in their families it compels them to return home. If the person is the oldest male child in the family and there is no body to take care of the family house such a person has to come back home to take up that responsibility. Also for some such leadership may be as a result of death of parents or all elderly members of the family [Focus Group Discussion conducted at conducted at Veiri].

The fact that return migrations were dominated by family reasons gives credence to the historical structural theory and re-enforce the conceptual framework as well (see sections 2.1 and 2.2). The coercive nature of families is evident, where individual interests are subservient to family interest to the extent that people are coerced to return home from wherever they might have migrated, to perform family duties and responsibilities (Iglicka, 2010).

The education of children also induced return migrations in the Wa West District. Maura et al (2011) has attributed rural return migration to perceptions of the rural as a safe place, and also as a close-knit community and a good place to raise a family. One way to raise children is to educate them. Migrants by virtue of where they migrated to in rural southern Ghana might not be able to educate their children. These migrants were usually in the rural communities of southern Ghana where they lived several kilometres away from the nearest basic school. Also, migrants' economic status at their destination areas may also not permit them to educate their children. Some migrants place value in the education of their children consequently their return migration to origin communities in the Wa West District. The voice of a 44-year-old male returnee emphasized this point: I migrated to Sefwi to work in the Cocoa farms I have six children and they were all not schooling when we were in Sefwi. After sometime I realised I needed to give my children some education so I brought some back home to my sister so they can school.

As they progressed I realised I needed to support my sister to educate my children because she was here alone taking care of my children so I decided to return home [44-year-old male returnee from Kandeu Village].

\subsection{Conclusions and Recommendations}

As presented from the different theoretical viewpoints (Section 2.0); with the neoclassical theories postulating return migration to be due to failed economic motives of the migrant at the destination area and the new economics of labour migration theory arguing that return migration was possible only when the migrant achieves savings or investment targets. Hence a successful migration experience. The evidence in this research proves the dominance of individual level factors influencing return migrations of people to the Wa West District. The findings do not indicate inability of migrants to accrue savings or failed economic motives. Rather they point to contextual and structural factors in the origin communities influencing return migrations to the Wa West District. These factors re-enforcethe structural theory because they could be described as contextual. Consequently, the study of rural return migrations must be broadened to consider all contextual factors and to enhance a better understanding of why people return to their rural origin communities.

Whiles appreciating these dynamics, it is also recommended that stakeholders including chiefs, elders, assembly members and opinion leaders and the District Assembly in the study area should conscientise returnees in the district through public fora, to plan their return migrations by initiating income generating ventures or establish businesses to make their return migrations beneficial to families and communities at large.

\section{References}

Adebo, G. M., \&Sekumade, A. B. (2012). Socio-Economic Influence of Retirees’ Migration on Rural Development in Ekiti State, Nigeria. International Journal of Humanities and Social Science. 2(12), pp.1-9.

Adu-Okoree, B. I. (2012). Let us pause before sending them: An Appraisal of the Socio Economic Condition of Return Migrants in Tamale, Ghana. Journal of Research in Peace, Gender and Development, 2(6), pp. 149-155.

Ainsaar, M. (2004). Reasons for Move: A Study on Trends and Reasons of Internal Migration with particular interest in Estonia 1989 - 2000.Tartu: Tartu University Press

Amin, S. (1974). Modern Migrations in Western Africa. Oxford: Oxford University Press. 
Awumbila, M., and Agyei-Mensah, S. (2009).Migration and voting patterns: exploring the linkages in two migrant communities in Ghana. Paper submitted to the Population Association of America Conference to be held in Detroit, USA. 30 April -2 May, 2009

Babbie, E. (2010). The Practice of Social Research (13th ed.). Belmont, CA: Wadsworth.

Babbie, E. (2007). The Practice of Social Research (11th ed.). Belmont, CA: Wadsworth.

Beauchemin, C., and Bocquier, P. (2011). Rural-Urban Migration in West Africa: Towards a Reversal? Migration Trends and Economic Situation in Burkina Faso and Cote d'Ivoire. Population Space and Place. 17(1), pp. 4772

Black, R., and Castaldo, A. (2008). Return Migration and Entrepreneurship in Ghana and Côte D'ivoire: The role of capital transfers. UK: Blackwell Publishing Ltd.

Black, R., Koser, K., Munk, K., Atfield, G., D’Onofrio, L., \&Tiemoko, R. (2004). Understanding voluntary return, Home Office Online Report 50/04, London: Home Office. Research, Development and Statistics Directorate.

Black, R., King, R., and Litchfield, J. (2003). Transnational Migration, Return and Development in West Africa. Sussex, UK: Sussex Centre for Migration Research, University of Sussex.

Boateng, W. (2012). Evaluating the efficacy of Focus Group Discussion (FGD) in Qualitative Social Research. International Journal of Business and Social Science, 3(7), pp. 54-57.

Cassarino, J. P. (2004). Theorising Return Migration: The Conceptual Approach to Return Migrants Revisited. International Journal on Multicultural Societies, 6(2), pp. 253-279.

Castles,S., and Miller, M. J. (2009). The Age of migration: International Population Movements in the Modern World (4th ed.). Basingstoke: Palgrave MacMillan.

Castelli, F., (2018). Drivers of migration: why do people move? Journal of Travel Medicine, Volume 25, Issue 1

Castles, S., and Miller, M. J. (2003). The Age of Migration: International Population Movements in the Modern World (3rd ed.). London: Macmillan.

Cromartie, J. B., Von Reichert, C. and Arthun, O. R. (2015). Factors Affecting Former Residents' Returning to Rural Communities. United States Department of Agriculture: Economic ResearchReport Number 185.

Crow, H. (2010). Factors Influencing Rural Migration Decisions in Scotland: An Analysis of the Evidence.Edinburgh: Queens Printers of Scotland.

De Haans, H. (2008). Migration and Development: A Theoretical Perspective. International Migration Institute Working Paper No.9, Oxford: University of Oxford.

Gandaa, M. D. (2013). Aspects of Birifor Phonology. University of Ghana, Legon: Accra. Ghana Statistical Service 2012. 2010 Population and Housing Census: Summary of final report. Accra: Ghana Publishers.

Gunder, A. F. (1969). Capitalism and Underdevelopment in Latin America. New York: Monthly Review Press.

Hirvonen, K., and Helene, B. L. (2012).Will they return? Evidence on internal return migration in Rural Tanzania.World Development 70, pp. 186-202.

Iglicka, K. (2010). Returns of Poles after 2004: Results of the Quantitative Research. Warsaw: University of Warsaw press.

International Organisation for Migration (2018). World migration Report. Switzerland: International Organisation for Migration

Junge, V., Revilla D. J., and Schätzl, L. (2013). Determinants and consequences of internal return migration in Thailand and Vietnam. World Development 71, pp. 94-106

Koehler, J., Laczko, F., Aghazarm, C. and Schad, J. (2010). Migration and the Economic Crisis in the European Union: Implications for Policy, Research and Publications Division. Geneva:International Organization for Migration.

Koser, K (2013) 'Migrants and refugees', in P Crang, M Crang, M Goodwin (eds) Introducing Human Geographies, 3rd Edition, London: Routledge, pp.556-71.

Krejcie, R.V. \& Morgan, D. W. (1970). Small-Sample Techniques. Journal of Educational and Psychological Measurement 30 (3), pp. 607-610.

Kwankye, S. O. (2012). Transition into Adulthood: Experiences of Return Independent Child Migrants in Northern Ghana. The Journal of Multicultural Society, 3(1), pp.1-24.

Maura, F., Marie, M., and McDonagh, J. (2011). The Rural as a Return Migration Destination. European Countryside1, pp. 31-44.

Mbiti, J. (1975). Introduction to African Religion (2nd ed.). Nairobi: East African Educational Publishers, Ltd.

Morawska, E. (2012). Historical-Structural Models of International Migration, In Martiniello, M. and Rath, J. 2012 An Introduction toInternational Migration Studies, Amsterdam: Amsterdam University Press.

Nukunya, G. K. (2000). Tradition and change in Ghana: An introduction to Sociology (2 ${ }^{\text {nd }}$ ed.). Ghana Universities Press: Accra. 
Piotrowski, M., and Tong, Y. (2010). Economic and Non-Economic Determinants of Return Migration: Evidence from rural Thailand. Population-E, 65(2), pp. 333-348.

Rosalind, E., and Holland, J. (2013).What is Qualitative Interviewing? New York: Bloomsbury Publishing Plc.

Stark, O. and Bloom, D. E. (1985). The New Economics of Labour Migration. American Economic Review, 75(2), pp. 173-178.

Stark, O., \&Levhari, D. (1982). On Migration and Risk in Less Developing Countries. Economic Development and Cultural Change 31, pp. 96-191.

Stark, O. (1980). On the Role of Urban-to-Rural Remittances in Rural Development. Journal ofDevelopment Studies 16, pp. 369-374.

Thomas-Hope, E. (2002). Trends and Patterns of Migration to and from Caribbean Countries. International Migration Papers, no. 50. Geneva: International Labour Organisation.

Tenkorang, J., A. (2014). Factors Associated with return migration to the Wa Municipality. Masters Dissertation. University of Ghana, Legon

Tonah, S. (2007). Ethnicity, conflict and consensus in Ghana, Accra: Woeli Publishing

Van der Geest, S. (2008). Resilience and the Whims of Reciprocity in Old Age: An examplefrom Ghana. MedischeAntropologie, 20 (2) 297-313.

Vercelli, M. B. (2006). Performance Practice of the Dagara-Birifor Gyil Tradition through theAnalysis of the Bewaa and Daarkpen Repertoire. Tucson: University of Arizona.

Wa West District Assembly (2013). Composite Budget of the Wa West District Assembly. WaWest District, Upper West Region.

Wallerstein, I. (1980). The Modern World System ii, Mercantalism and the Consolidation of the European World Economy, 1600-1750.New York: Academic Press.

Walter, M. (2010). The Nature of Social Science Research. Oxford University Press: Oxford

Yendaw, E., Augustine Tanle, A., \& Kendie, S., B. (2017). Reintegration Experiences of Internal Return Migrants in the Wa Municipality, Ghana. Journal of Identity and Migration Studies, Volume 11, number 2

Yendaw, E., Dakyaga, F., Tanle, A., \&Tampah, A., M., (2016). Drivers of north-south migration in the Wa West District: Economic returns or migrants' sub-culture. Journal of African Studies and Development. Vol.8 (6), pp. $67-80$ 